\title{
A further case of the recurrent $15 q 24$ microdeletion syndrome, detected by array CGH
}

\author{
Eva Klopocki • Luitgard M. Graul-Neumann • \\ Ulrike Grieben • Holger Tönnies • Hans-Hilger Ropers • \\ Denise Horn • Stefan Mundlos • Reinhard Ullmann
}

Received: 24 May 2007 / Accepted: 19 September 2007 /Published online: 12 October 2007

(C) Springer-Verlag 2007

\begin{abstract}
We report on a 10-year-old patient with developmental delay, craniofacial dysmorphism, digital and genital abnormalities. In addition, muscular hypotonia, strabism, and splenomegaly were observed; inguinal and umbilical hernias were surgically corrected. Mucopolysaccharidoses and CDG syndromes could not be found. Chromosome analysis revealed a normal male karyotype $(46, \mathrm{XY})$. A more detailed investigation of the patient's genomic DNA by microarraybased comparative genomic hybridization (array $\mathrm{CGH}$ ) detected an interstitial $3.7 \mathrm{Mb}$ deletion ranging from $15 \mathrm{q} 24.1$ to $15 \mathrm{q} 24.3$ which was shown to be de novo. Interstitial deletions involving $15 \mathrm{q} 24$ are rare. Sharp et al. (Hum Mol Genet 16:567-572, 2007) recently characterized a recurrent $15 \mathrm{q} 24$ microdeletion syndrome with breakpoints in
\end{abstract}

This project was supported by the European Fund for Regional Development.

\section{E. Klopocki $(\bowtie) \cdot$ D. Horn $\cdot$ S. Mundlos}

Institute of Medical Genetics, Charité Universitätsmedizin Berlin,

Campus Virchow Klinikum, Augustenburger Platz 1,

13353 Berlin, Germany

e-mail: eva.klopocki@charite.de

\section{M. Graul-Neumann $\cdot$ H. Tönnies}

Institute of Human Genetics, Charité Universitätsmedizin Berlin, Augustenburger Platz 1,

13353 Berlin, Germany

\section{U. Grieben}

Department of Neuropaediatrics,

Charité Universitätsmedizin Berlin,

Augustenburger Platz 1,

13353 Berlin, Germany

H.-H. Ropers $\cdot$ S. Mundlos $\cdot$ R. Ullmann

Max-Planck Institute for Molecular Genetics,

Ihnestrasse 63,

Berlin, Germany regions of segmental duplications. The de novo microdeletion described here colocalizes with the minimal deletion region of the $15 \mathrm{q} 24$ microdeletion syndrome. The distinct clinical phenotype associated with this novel microdeletion syndrome is similar to the phenotype of our patient with respect to specific facial features, developmental delay, microcephaly, digital abnormalities, and genital abnormalities in males. We present a genotype-phenotype correlation and comparison with patients from the literature.

Keywords $15 \mathrm{q} 24 \cdot$ Microdeletion · Array CGH

$\begin{array}{ll}\text { Abbreviations } \\ \text { Array CGH } & \begin{array}{l}\text { microarray-based comparative } \\ \text { genomic hybridization }\end{array} \\ \text { BAC } & \begin{array}{l}\text { bacterial artificial chromosome } \\ \text { copy number variation }\end{array} \\ \text { CNV } & \text { fluorescence in situ hybridization } \\ \text { FISH } & \text { percentile } \\ \text { P } & \end{array}$

Introduction

Microdeletion syndromes are recurrent deletions associated with a distinct phenotype. These microdeletions often occur between low copy repeats and are commonly due to liability to unequal crossing over. It was recently shown that the well known classical microdeletion syndromes such as DiGeorge and Williams syndromes account for about 5\% of all patients with mental retardation [18]. Besides the detection of known microdeletion syndromes, microarraybased comparative genomic hybridization (array CGH) or molecular karyotyping recently led to the discovery of novel recurrent microdeletion syndromes such as $17 \mathrm{q} 21.31$ 
and $15 \mathrm{q} 24[12,20,21]$. To date 14 patients have been reported who have interstitial deletions at 15q22-q24 [1, 3, 4, $7,13,20,22]$, but only three of them are restricted to chromosomal band $15 q 24$ [4, 20]. So far, only a few of these cases have been molecularly characterized in order to determine the size of the affected regions. Despite considerable phenotypic variability, patients with $15 \mathrm{q} 24$ microdeletion syndrome share common features including global developmental delay, hypotonia, and genital abnormalities in males. In order to further delineate the $15 \mathrm{q} 24$ genotype-phenotype correlation, a novel patient with $15 \mathrm{q} 24$ microdeletion detected by array CGH is presented.

\section{Clinical report}

We present a boy who is the second child of healthy Caucasian parents. The mother underwent spine CT scan in the 8 th week of gestation. The further course of pregnancy was uneventful and delivery by Caesarean section was at 38 weeks of gestation after preterm hydrorrhoea. Physical examination at the age of 10 years revealed a height of $132.5 \mathrm{~cm}$ (P50), weight of $35.7 \mathrm{~kg}$ (P50-75) and head circumference of $53.5 \mathrm{~cm}(\mathrm{P} 75)$. Our patient presented with developmental retardation, craniofacial dysmorphism, truncal obesity, and micropenis (Fig. 1a,b). In addition, general muscular hypotonia and splenomegaly were observed. $\mathrm{He}$ showed lumbar hyperlordosis, mild genua valga, and joint hypermobility. At the age of 6 months coordination disturbances were noted. Unaided walking was possible at 18 months.
Speech development was retarded and a mild mental retardation (IQ 65) was observed. Nasal speech and a hoarse voice were apparent. Prominent veins were evident on the trunk. Skin laxity was noted especially in the face and hands. We observed a convergent squint, astigmatism, and amblyopia. Inguinal and umbilical hernias as well as unilateral retentio testis inguinalis were surgically corrected at age 4 years. Patient's hands show mild brachydactyly, clinodactyly of fourth finger (left hand), and broad thumbs (Fig. 1c,d). Radiological investigations including cranial CT were normal except for hand radiographs disclosing hypoplasia of distal phalanges, short mesophalanges, delay of carpal ossification (corresponding to the state of a 3 year old child), irregular epiphyses of the second and fifth mesophalanges and of the distal phalanx of the thumb (Fig. 1e).

Echocardiography as well as renal ultrasound and neurophysiological investigations (i.e. nerve velocity, EEG, ECG) did not reveal any pathological findings. In repeated metabolic screenings triglycerides and the LDL/HDL quotient were always elevated. He was only able to walk up to $100 \mathrm{~m}$. Clinically, a metabolic defect was suspected. However, examinations concerning mucopolysaccharidoses and CDG syndrome disclosed no abnormalities. All serum parameters including growth related factors (IGF1, IGFBP3) were normal. FSH $(18 \mathrm{U} / \mathrm{l})$ and testosterone $(1.4 \mathrm{ng} / \mathrm{ml})$ values were normal for the patient's age. This study was approved by the ethics committee of the Charité, Universitätsmedizin Berlin, and all individuals gave their informed consent prior to their inclusion in the study.
Fig. 1 a, b Patient at the age of 10 years. Note truncal obesity, widely spaced, inverted nipples, as well as coarse face with high forehead, broad medial eyebrows, periorbital fullness, slight antimongoloid slant, deep set eyes, hypoplastic nostrils, long philtrum and full cheeks. c, d Hands show mild brachydactyly, clinodactyly of fourth finger (left hand) and broad thumbs. e Note hypoplasia of the distal phalanges, short mesophalanges, delayed carpal ossification (corresponding to the state of a 3 year old child), irregular epiphyses of the second and fifth mesophalanges and of the distal phalanx of the thumb
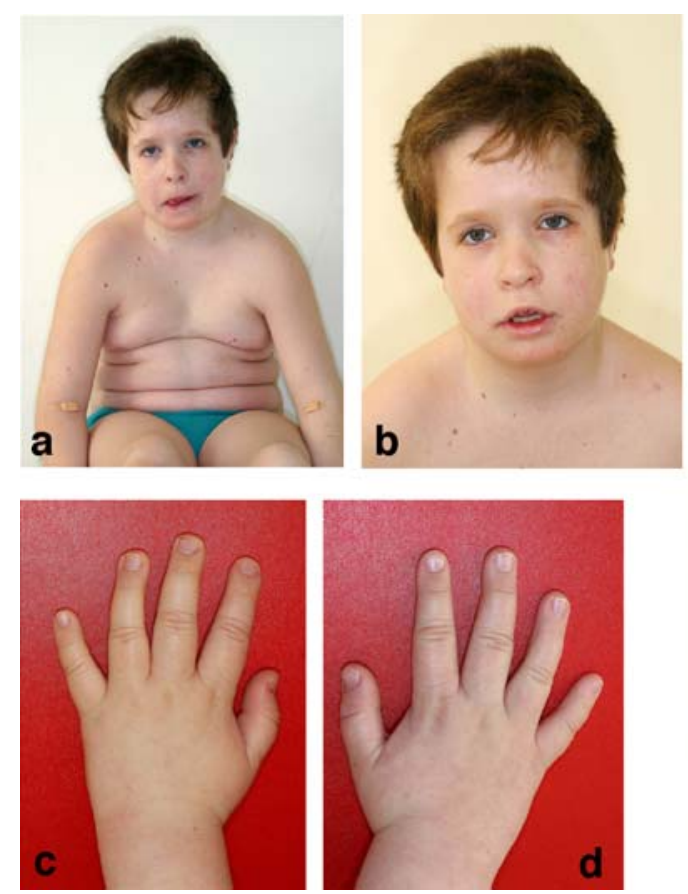

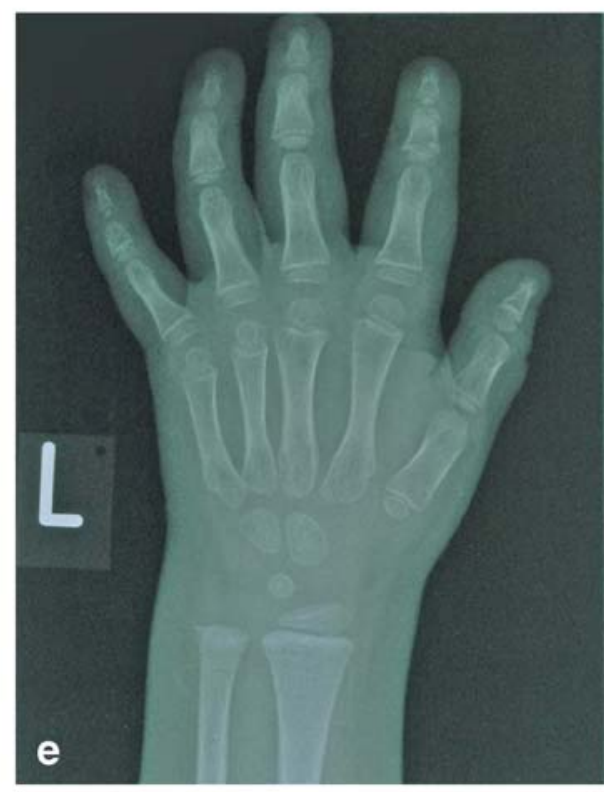




\section{Materials and methods}

Cytogenetics

Karyotyping of GTG-banded chromosomes from lymphocytes at 450 bands resolution was performed according to standard procedures.

Fluorescence in situ hybridization (FISH)

BAC clones RP11-414J4 (genomic position 72.7-72.9 Mb) and RP11-94P14 (genomic position 75.2-75.3 Mb) were obtained from the RZPD (Deutsches Ressourcenzentrum für Genomforschung, Berlin, Germany). Genomic positions are according to the Ensembl Genome Browser v44, April 2007. BAC DNA was fluorescently labelled using nick translation and hybridized to metaphase spreads of the patient's and parents' lymphocytes using standard procedures. BAC clones RP11-414J4 and RP11-94P14 were labelled with spectrum orange. Centromere probe, Cep15 (D15Z1; Vysis, Downers Grove, IL), labelled with spectrum green was used as control probe. Chromosomes were counterstained with DAPI (4',6-diamidino-2-phenylindole). Hybridization of the commercial probes for SNRPN (PraderWilli/Angelman region) and TUPLE1 (DiGeorge/VCFS region) were performed on metaphase spreads of the patient as recommended by the manufacturer (Vysis, Downers Grove, IL).

Microarray-based comparative genomic hybridization (array $\mathrm{CGH}$ )

Array CGH was carried out using a submegabase whole human genome tiling path BAC array consisting of the human 32k Re-Array set (http://bacpac.chori.org/pHumanMinSet. htm) [14, 18], the $1 \mathrm{Mb}$ Sanger Clone set (Wellcome Trust Sanger Institute) [6], and a set of 390 subtelomeric clones (generated in the course of the EU initiative COSTB19: Molecular cytogenetics of solid tumours). Detailed protocols are available at the following webpage: http:/www.molgen. mpg.de/ abt_rop/molecular_cytogenetics/Protocols.html. Array CGH was performed as described previously [11] and 33028 BACs were included in the analysis. The log2ratio of test to reference was calculated and plotted according to chromosomal position of the clones. Copy number gains and losses were determined by a conservative threshold of 0.3 and -0.3 , respectively. Profile deviations consisting of three or more neighbouring $\mathrm{BAC}$ clones were considered as genomic aberrations and were further evaluated by FISH, unless they coincided with a published variant as listed in the Database of Genomic Variants (http://projects.tcag.ca/variation/; version Oct. 11, 2006). For visualizing the content of low copy repeats in the ratio plots (Fig. 2a,b), each BAC clone was classified into one out of seven categories and colour-coded as described previously [2].

\section{Results}

Standard karyotyping of G-banded chromosomes did not reveal any chromosomal abnormalities. According to the FISH analyses there was no evidence for a deletion of the Prader-Willi syndrome region or a microdeletion $22 \mathrm{q} 11.2$. Therefore, we performed array $\mathrm{CGH}$ analysis with the patient's genomic DNA using a submegabase resolution whole genome tiling path array to detect microdeletions or duplications. A submicroscopic interstitial deletion on chromosome 15q24.1-q24.3 represented by 33 BAC clones was detected (Fig. 2). The size of the deletion is approximately $3.7 \mathrm{Mb}$ extending from $72.2 \mathrm{Mb}$ to $75.9 \mathrm{Mb}$ (Ensembl release 43; Feb. 2007). According to the array $\mathrm{CGH}$ data the two breakpoints are located between RP11-247C02 and RP11-672A20 (proximal breakpoint) and RP11-758J16 and RP11-745I11 (distal

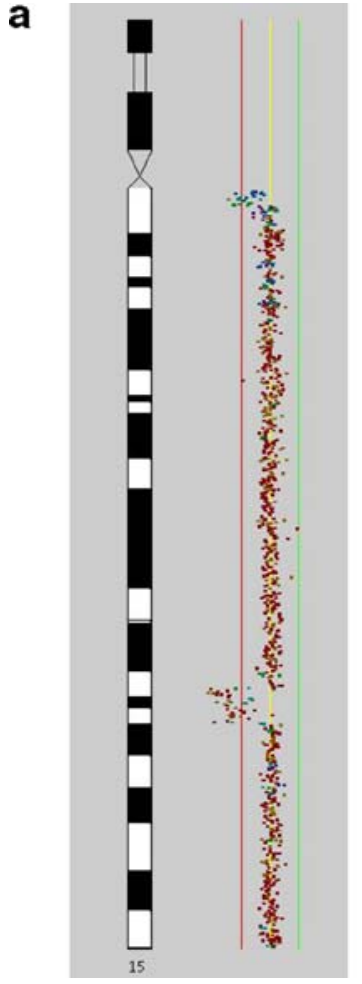

b

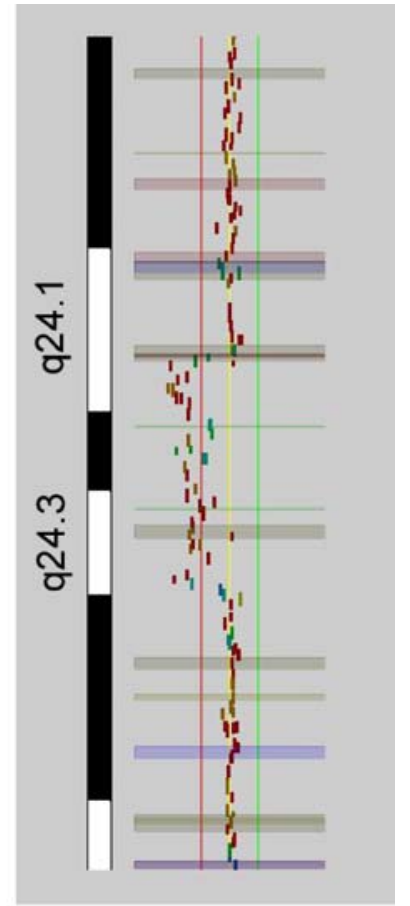

Fig. 2 a Array CGH profile of chromosome 15 visualized using CGHPRO software. Each spot represents one BAC clone on the array. The red and green lines indicate the log2ratio thresholds -0.3 (loss) and 0.3 (gain), respectively. Note: the aberration close to the centromere on $15 \mathrm{q} 11.2$ constitutes a known $\mathrm{CNV}$ indicated by the turquoise colour of the spots. b Detailed view of the interstitial deletion on chromosome $15 \mathrm{q} 24$. The microdeletion is flanked by lowcopy repeats indicated by the turquoise colour of the spots. Horizontal bars represent DNA copy number variants as listed in the Database of Genomic Variants (Dec. 2005) 
breakpoint). Both breakpoints were found to be enriched for low copy repeats, which, according to the Segmental Duplication Database (http://humanparalogy.gs.washington. edu/), share a $49.9 \mathrm{~kb}$ segment with $95 \%$ sequence similarity (no .9417), and the proximal breakpoint coincided with published DNA copy number variants. Given this high sequence similarity the deletion most likely emerged through nonallelic homologous recombination (NAHR) of the two breakpoint flanking low copy repeats (LCRs), a mechanism associated with genomic rearrangements [16]. The deleted region comprises 39 annotated genes (based on v39, June 2006, Ensembl genome browser; (http://www. ensembl.org). In addition, a deletion on $15 \mathrm{q} 11.2$ was observed which represents a CNV listed in the Database of Genomic Variants and was therefore considered as a benign variant without pathological relevance.

For verification of array CGH data by FISH we used a set of BAC clones mapping to $15 \mathrm{q} 24$. As expected from the array data $(\log 2$ ratio $<-0.3)$ only one signal on the patient's metaphases was detected for BAC clones RP11414J4 and RP11-94P14 (data not shown). FISH on metaphase chromosomes of the patient's parents and his brother detected two signals on chromosome 15 for all probes investigated and karyotypes were normal (data not shown). Thus, the aberration observed in our patient occurred de novo.

\section{Discussion}

Recently, Sharp et al. described a recurrent microdeletion of $15 \mathrm{q} 24$ in four cases ranging in size from 1.7-3.9 Mb characterised by molecular cytogenetic techniques [21]. The minimal deletion region was delineated to be $1.7 \mathrm{Mb}$ in

Fig. 3 Schematic representation of 15 q24 region. The three recurrent breakpoints as delineated by Sharp et al. [21] as well as the deletion sizes of the presented case and published cases are indicated. The critical region is located between the recurrent breakpoints BP1 and BP2 size $(72.15-73.85 \mathrm{Mb})$. The patient presented here constitutes an interstitial microdeletion at $15 \mathrm{q} 24$ which shares common proximal (BP1) and distal breakpoints (BP3) with cases IMR349 and C45/06 of the publication by Sharp et al. [21] (Fig. 3). Since all deletions occurred in the maternal lineage the possibility of an underlying imprinting effect was pointed out [21]. The parental origin of the deletion was not analysed in our patient. A clinical comparison of our patient to these patients from the literature is shown in Table 1. The phenotype between patients with microdeletion $15 \mathrm{q} 24$ is variable; however, our patient shares all of the major features described for 15q24 microdeletion syndrome by Sharp et al. [21], i.e. unusual facial features (high frontal hairline, broad medial eyebrows, downslanted palpebral fissures, and long philtrum), developmental delay, digital abnormalities, genital abnormalities, and loose connective tissue (manifestation: joint laxity, inguinal hernia). However, our patient does not present with microcephaly (3/4), prenatal and postnatal growth deficiency (3/4), hearing problems $(2 / 4)$, or bowel atresia $(2 / 4)$.

Among the deleted genes are several coding for enzymes, e.g. mannose phosphate isomerase (MPI), alpha-mannosidase 2C1 (MAN2C1), and alpha-subunit of electron transfer flavoprotein (ETFA), as well as the cytochrome P450 sidechain cleavage enzyme (P450scc) which catalyzes the first step in steroidogenesis. Several of these enzymes are involved in the synthesis, export, and degradation of glycoproteins. Mutations in the MPI gene (MIM 154550) cause congenital disorder of glycosylation type $\mathrm{Ib}$ (CDG Ib) [9, 19]. CDG Ib is an autosomal recessive disorder showing abnormalities in the glycosylation of glycoproteins. Therefore, the haploinsufficiency is asymptomatic. MAN2C1 (MIM 154580) is involved in the degradation of oligomannosides derived from dolichol intermediates, the degradation of newly synthesized glyco-

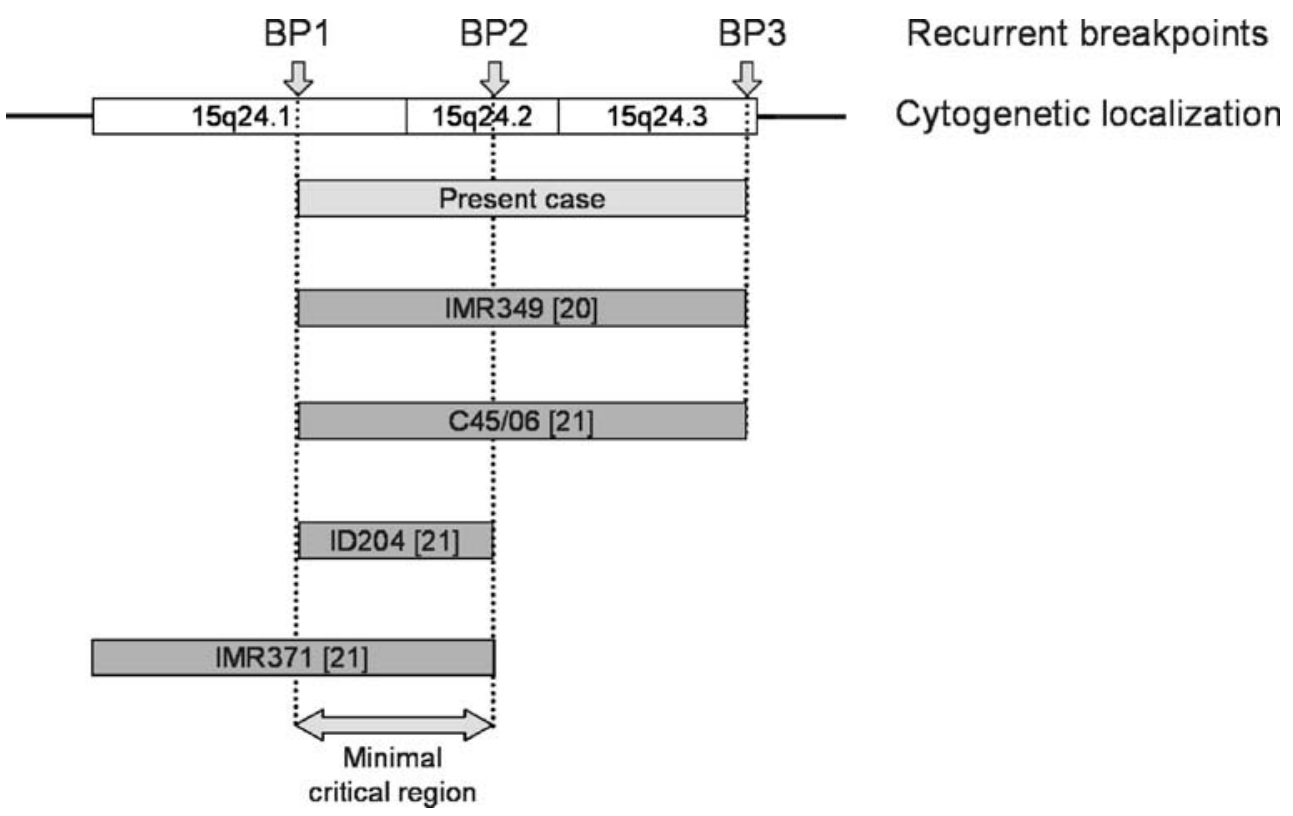


Table 1 Phenotypic comparison of patients with interstitial 15q24 deletion

\begin{tabular}{|c|c|c|c|c|c|c|c|}
\hline & Male, 10 years & $\begin{array}{l}\text { Cushman et } \\
\text { al. [4] } \\
\text { Patient } 1 \\
\text { Male, } \\
23 \text { months }\end{array}$ & $\begin{array}{l}\text { Cushman } \\
\text { et al. [4] } \\
\text { Patient } 2 \\
\text { Female, } \\
11 \text { years }\end{array}$ & $\begin{array}{l}\text { Sharp et al. [20] } \\
\text { IMR349 }\end{array}$ & $\begin{array}{l}\text { Sharp et al. [21] } \\
\text { IMR } 371\end{array}$ & $\begin{array}{l}\text { Sharp et al. } \\
\text { [21] ID204 }\end{array}$ & $\begin{array}{l}\text { Sharp et al. } \\
\text { [21] C45/06 } \\
\text { Male, } \\
14 \text { years }\end{array}$ \\
\hline Short stature & - & - & - & + & - & + & + \\
\hline Hypotonia & + & + & + & ND & ND & ND & + \\
\hline $\begin{array}{l}\text { Developmental } \\
\text { delay/mental } \\
\text { retardation }\end{array}$ & + & + & + & + & + & Mild & + \\
\hline Microcephaly & - & - & - & + & - & + & + \\
\hline Strabismus & + & + & ND & - & - & + & + \\
\hline Hypertelorism & - & - & ND & + & + & + & + \\
\hline Micrognathia & - & + & ND & - & - & - & - \\
\hline Palate anomaly & - & - & + & + & - & - & - \\
\hline Full lower lip & - & & & + & + & + & + \\
\hline Ear anomaly & - & + & ND & + & - & + & + \\
\hline Epicanthal folds & - & + & ND & - & - & + & - \\
\hline $\begin{array}{l}\text { High frontal } \\
\text { hair line }\end{array}$ & + & & ND & + & + & + & + \\
\hline $\begin{array}{l}\text { Broad medial } \\
\text { eyebrows }\end{array}$ & + & & ND & + & + & + & + \\
\hline $\begin{array}{l}\text { Long/smooth } \\
\text { philtrum }\end{array}$ & + & & ND & + & + & + & + \\
\hline $\begin{array}{l}\text { Downslanted } \\
\text { palpebral } \\
\text { fissures }\end{array}$ & + & ND & ND & + & - & + & + \\
\hline Hernia & $\begin{array}{l}\text { Inguinal and } \\
\text { umbilical }\end{array}$ & - & ND & - & $\begin{array}{l}\text { Diaphragmatic, } \\
\text { inguinal and } \\
\text { hiatal }\end{array}$ & - & - \\
\hline $\begin{array}{l}\text { Genital } \\
\text { anomaly }\end{array}$ & Micropenis & $\begin{array}{l}\text { Micropenis, } \\
\text { small } \\
\text { scrotum }\end{array}$ & ND & - & $\begin{array}{l}\text { Coronal } \\
\text { hypospadias with } \\
\text { phimosis }\end{array}$ & $\begin{array}{l}\text { Mild } \\
\text { hypospadias }\end{array}$ & Hypospadias \\
\hline $\begin{array}{l}\text { Musculoskeletal } \\
\text { anomaly }\end{array}$ & $\begin{array}{l}\text { Joint laxity, } \\
\text { clinodactyly of } \\
\text { fourth finger } \\
\text { (left hand), } \\
\text { Brachymeso- } \\
\text { phalangy V }\end{array}$ & $\begin{array}{l}\text { Clinodactyly } \\
\text { of fifth } \\
\text { fingers, } \\
\text { distal } \\
\text { tapering of } \\
\text { fingers }\end{array}$ & ND & $\begin{array}{l}\text { Joint laxity, long } \\
\text { slender fingers, } \\
\text { proximally } \\
\text { implanted } \\
\text { thumbs, sandal } \\
\text { gap, scoliosis }\end{array}$ & $\begin{array}{l}\text { Joint laxity, } \\
\text { hypoplastic right } \\
\text { thumb, } \\
\text { contractures of } \\
\text { fingers, pes cavus, } \\
\text { camptodactyly of } \\
\text { toes }\end{array}$ & $\begin{array}{l}\text { Joint laxity, } \\
\text { small hands, } \\
\text { distal brachy- } \\
\text { dactyly, mild } \\
\text { cutaneous } \\
\text { syndactyly }\end{array}$ & $\begin{array}{l}\text { Proximal } \\
\text { implanted } \\
\text { thumbs, } \\
\text { scoliosis }\end{array}$ \\
\hline
\end{tabular}

+ feature present, - feature absent, $N D$ feature not described

proteins, and in the processing of free oligosaccharides that are formed in the cytosol [23]. Secretory carrier membrane proteins (SCAMP2, SCAMP5) are a family of post-Golgi and Golgi membrane proteins which have been implicated in vesicular trafficking. SCAMPs interact with NHE7 $\left(\mathrm{Na}^{+} / \mathrm{H}^{+}\right.$ exchanger) and participate in the shuttling and retrieval of NHE7 from peripheral recycling endosomes to the trans-Golgi network [15]. Mucopolysaccharidoses and CDG syndrome were ruled out biochemically. However, the second allele was not analysed for point mutations. Thus, we cannot exclude uncovering of a recessive condition which could result in a homozygous loss of alleles which leads to deficiency of one of the other enzymes in this region.
The cholesterol side chain cleavage enzyme P450scc is responsible for the conversion of cholesterol to pregnenolone in mitochondria [17]. This is the first and rate-limiting step in steroidogenesis [17]. So far, only one patient with a heterozygous mutation in P450scc has been described [24]. This patient had a late-onset form of congenital lipoid adrenal hyperplasia without the characteristic enlargement of the adrenals. A complete absence of P450scc activity causes congenital adrenal insufficiency, complete 46,XY sex reversal, and severe adrenal failure $[8,10]$. Congenital adrenal hyperplasia is a severe disorder with an impairment of adrenal and gonadal steroid synthesis. Although, we did not observe such a severe phenotype, and current steroid levels 
are normal in our patient. The haploinsufficiency of P450scc might contribute to the genital abnormalities in our patient and other affected male patients (microphallus with small scrotum, undescended testes, hypospadias) with deletions spanning the P450scc locus on 15q24.1 [4, 20].

In summary, the patient presented here constitutes an interstitial microdeletion at $15 \mathrm{q} 24$ and represents another case of the recently described $15 \mathrm{q} 24$ microdeletion syndrome. This is another example of the impact of array CGH as a diagnostic tool in clinical medicine [5].

Acknowlegdements The authors thank Fabienne Trotier, Karen Stout-Weider, and Milena Vetter for their excellent technical assistance in the array CGH and FISH experiments. We are also grateful to the patient and his family for their collaboration in this study. Additionally, we thank Pieter de Jong and the BACPAC Resources Centre for providing the DNA of the human 32k Re-array set, the COST B19 Action for the clones of the subtelomeric set, Nigel Carter and the Mapping Core and Map Finishing groups of the Wellcome Trust Sanger Institute for initial clone supply and verification of the $1 \mathrm{Mb}$ array, as well as Claus Hultschig for spotting the arrays.

\section{References}

1. Bettelheim D, Hengstschlager M, Drahonsky R, Eppel W, Bernaschek G (1998) Two cases of prenatally diagnosed diaphragmatic hernia accompanied by the same undescribed chromosomal deletion (15q24 de novo). Clin Genet 53(4):319-320

2. Chen W, Erdogan F, Ropers H, Lenzner S, Ullmann R (2005) CGHPRO - a comprehensive data analysis tool for array CGH. BMC Bioinformatics 6:85

3. Clark RD (1984) Del(15)(q22q24) syndrome with Potter sequence. Am J Med Genet 19(4):703-705

4. Cushman LJ, Torres-Martinez W, Cherry AM, Manning MA, Abdul-Rahman O, Anderson CE, Punnett HH, Thurston VC, Sweeney D, Vance GH (2005) A report of three patients with an interstitial deletion of chromosome 15q24. Am J Med Genet A 137(1):65-71

5. Denayer E, Legius E (2007) What's new in the neuro-cardiofacial-cutaneous syndromes? Eur J Pediatr 166(11):1091-1098 DOI 10.1007/s00431-007-0535-7

6. Fiegler H, Carr P, Douglas EJ, Burford DC, Hunt S, Scott CE, Smith J, Vetrie D, Gorman P, Tomlinson IP, Carter NP (2003) DNA microarrays for comparative genomic hybridization based on DOP-PCR amplification of BAC and PAC clones. Genes Chromosomes Cancer 36(4):361-374

7. Formiga LD, Poenaru L, Couronne F, Flori E, Eibel JL, Deminatti MM, Savary JB, Lai JL, Gilgenkrantz S, Pierson M (1988) Interstitial deletion of chromosome 15: two cases. Hum Genet 80(4):401-404

8. Hiort O, Holterhus PM, Werner R, Marschke C, Hoppe U, Partsch CJ, Riepe FG, Achermann JC, Struve D (2005) Homozygous disruption of P450 side-chain cleavage (CYP11A1) is associated with prematurity, complete $46, \mathrm{XY}$ sex reversal, and severe adrenal failure. J Clin Endocrinol Metab 90(1):538-541

9. Jaeken J, Matthijs G (2001) Congenital disorders of glycosylation. Annu Rev Genomics Hum Genet 2:129-151

10. Katsumata N, Ohtake M, Hojo T, Ogawa E, Hara T, Sato N, Tanaka T (2002) Compound heterozygous mutations in the cholesterol side-chain cleavage enzyme gene (CYP11A) cause congenital adrenal insufficiency in humans. J Clin Endocrinol Metab 87(8):3808-3813
11. Klopocki E, Neumann LM, Tonnies H, Ropers HH, Mundlos S, Ullmann R (2006) Ulnar-mammary syndrome with dysmorphic facies and mental retardation caused by a novel $1.28 \mathrm{Mb}$ deletion encompassing the TBX3 gene. Eur J Hum Genet 14:1274-1279

12. Koolen D, Vissers L, Pfundt R, de Leeuw N, Knight S, Regan R, Kooy R, Reyniers E, Romano C, Fichera M, Schinzel A, Baumer A, Anderlid B, Schoumans J, Knoers N, van Kessel A, Sistermans E, Veltman J, Brunner H, de Vries B (2006) A new chromosome $17 \mathrm{q} 21.31$ microdeletion syndrome associated with a common inversion polymorphism. Nat Genet 38(9):999-1001

13. Kristoffersson U, Heim S, Mandahl N, Sundkvist L, Szelest J, Hagerstrand I (1987) Monosomy and trisomy of 15q24-qter in a family with a translocation $\mathrm{t}(6 ; 15)(\mathrm{p} 25 ; \mathrm{q} 24)$. Clin Genet 32 (3):169-171

14. Krzywinski M, Bosdet I, Smailus D, Chiu R, Mathewson C, Wye N, Barber S, Brown-John M, Chan S, Chand S, Cloutier A, Girn N, Lee D, Masson A, Mayo M, Olson T, Pandoh P, Prabhu AL, Schoenmakers E, Tsai M, Albertson D, Lam W, Choy CO, Osoegawa K, Zhao S, de Jong PJ, Schein J, Jones S, Marra MA (2004) A set of BAC clones spanning the human genome. Nucleic Acids Res 32(12):3651-3660

15. Lin P, Williams W, Luu Y, Molday R, Orlowski J, Numata M (2005) Secretory carrier membrane proteins interact and regulate trafficking of the organellar $(\mathrm{Na}+, \mathrm{K}+) / \mathrm{H}+$ exchanger NHE7. J Cell Sci 118:1885-1897

16. Lupski JR, Stankiewicz P (2005) Genomic disorders: molecular mechanisms for rearrangements and conveyed phenotypes. PLoS Genet 1(6): 49

17. Miller W (1988) Molecular biology of steroid hormone synthesis. Endocrinology Reviews 9:295-318

18. Osoegawa K, Mammoser AG, Wu C, Frengen E, Zeng C, Catanese JJ, de Jong PJ (2001) A bacterial artificial chromosome library for sequencing the complete human genome. Genome Research 11:483-496

19. Schollen E, Dorland L, de Koning TJ, Van Diggelen OP, Huijmans JG, Marquardt T, Babovic-Vuksanovic D, Patterson M, Imtiaz F, Winchester B, Adamowicz M, Pronicka E, Freeze H, Matthijs G (2000) Genomic organization of the human phosphomannose isomerase (MPI) gene and mutation analysis in patients with congenital disorders of glycosylation type Ib (CDG-Ib). Hum Mutat 16(3):247-252

20. Sharp AJ, Hansen S, Selzer RR, Cheng Z, Regan R, Hurst JA, Stewart H, Price SM, Blair E, Hennekam RC, Fitzpatrick CA, Segraves R, Richmond TA, Guiver C, Albertson DG, Pinkel D, Eis PS, Schwartz S, Knight SJ, Eichler EE (2006) Discovery of previously unidentified genomic disorders from the duplication architecture of the human genome. Nat Genet 38(9):1038-1042

21. Sharp AJ, Selzer RR, Veltman JA, Gimelli S, Gimelli G, Striano P, Coppola A, Regan R, Price SM, Knoers NV, Eis PS, Brunner HG, Hennekam RC, Knight SJ, de Vries BBA, Zuffardi O, Eichler EE (2007) Characterization of a recurrent 15q24 microdeletion syndrome. Hum Mol Genet 16(5):567-572

22. Spruijt L, Engelen JJ, Bruinen-Smeijsters IP, Albrechts JC, Schrander J, Schrander-Stumpel CT (2004) A patient with a de novo $15 \mathrm{q} 24 \mathrm{q} 26.1$ interstitial deletion, developmental delay, mild dysmorphism, and very blue irises. Am J Med Genet A 129 (3):312-315

23. Suzuki T, Hara I, Nakano M, Shigeta M, Nakagawa T, Kondo A, Funakoshi Y, Taniguchi N (2006) Man2C1, an alpha-mannosidase, is involved in the trimming of free oligosaccharides in the cytosol. Biochem J 400(1):33-41

24. Tajima T, Fujieda K, Kouda N, Nakae J, Miller W (2001) Heterozygous mutation in the cholesterol side chain cleavage enzyme (P450scc) gene in a patient with $46, \mathrm{XY}$ sex reversal and adrenal insufficiency. J Clin Endocrinol Metab 86:3820 3825 